\title{
The Determinants of Repeat Purchase Intention for Luxury Brands among Generation Y Consumers in Malaysia
}

\author{
Mohammad Hussain ${ }^{1}$ \\ ${ }^{1}$ Faculty of Business and Management, Asia Pacific University of Technology and Innovation, Kuala Lumpur, \\ Malaysia \\ Correspondence: Mohammad Hussain, Post Graduate School of Business Faculty of Business and Management, \\ Asia Pacific University of Technology and Innovation, 57000, Kuala Lumpur, Malaysia. E-mail: \\ zubairkhaleeq@hotmail.com
}

Received: June 29, 2017

doi:10.5539/ass.v13n9p125
Accepted: July 6, $2017 \quad$ Online Published: August 25, 2017

URL: https://doi.org/10.5539/ass.v13n9p125

\begin{abstract}
Repeat purchasing has now become a critical factor for marketers, especially in the luxury goods market. Repeat purchasing not only saves costs (as opposed to attracting new customers), but increases sales as well. Both past and current researchers have been keen in investigating what drives consumers to repeat their purchase. The purpose of this academic research is to examine the relationship between Hedonic Value (HV), Satisfaction (S), Consumer Inertia (CI) and Product Attribute (PA) with the Repeat Purchase Intention (RPI) for luxury brands among Generation Y consumers in Malaysia. As such, eight luxury brands have been selected to investigate the consumer behaviour of consumers in Malaysia, in relation to the repeat purchase intention. This is a quantitative study that collected data from 134 respondents. Findings reveal that Hedonic Value and Satisfaction have positive and significant correlation with Repeat Purchase Intention, with Satisfaction being the strongest predictor of Repeat Purchase Intention. The findings can be used by marketers in Malaysia to aid them in creating marketing strategies to maintain their current customer base, as well as attract new customers to purchase their luxury brands within their target market. This study can also motivate current researchers to further investigate in the field of luxury brands, in an attempt to bridge the gap between luxury brands and Repeat Purchase Intention.
\end{abstract}

Keywords: consumer inertia, hedonic value, luxury, product attribute, repeat purchase intention, satisfaction

\section{Introduction}

The term luxury has a broad meaning and its definition varies over time. As explained by David \& Chiari (2008), luxury was defined in the past as anything that fell outside the basic human necessities and was usually afforded by the rich. The authors further argue that now the luxurious need is not only linked to the consumers' psychological desires, but now evolving with consumer's dynamic cultural changes as well.

Lipovetsly (2007, pp. 30-35) has separated ideological luxury from material luxury, where the former is linked with sacred things such as altruism, intellectual and morality, and the latter shaping reality as a result of satisfaction arising from individualistic egocentric desires.

Today's luxury ranges from fashion, jewellery, leather, cosmetics, wines, hospitality to air and automobile brands (Okonkwo, 2009). Luxury, although being mostly an intangible consumption experience, has dramatically transitioned to a symbol of global prestige and usually represents 'unique' quality, design, fashion and status (Juggessur \& Cohen, 2009; Phau \& Prendergast, 2000a, cited in Miller \& Mills, 2012). Lipovetsky (2007, pp.69-74) says that although the luxury market seems to be dominated by female consumers, the market will subsequently balance itself to the male luxury counterparts.

The global luxury market has exceeded $€ 1 \mathrm{tn}$, and the value of personal luxury market goods (like jewellery, watches, leather goods, fashion, perfumes, etc.) is now worth $€ 253 \mathrm{bn}$ (Kollewe, 2015). The online market share of top 10 luxury brands holds a staggering 78.5\%, Ralph Lauren being number 1 (19.2\%) while Louboutin ranked at number 10 (1.8\%) (Colson, 2016).

The consumption of luxury brands is no longer limited to the rich western and developed countries. A market study done by D'Arpizio et al. (2015) found that Chinese consumers played a key part in global luxury spending 
growth, which account for $31 \%$ worldwide spending, followed by American and European consumers at $24 \%$ and $18 \%$ respectively. A similar study done by the same authors in 2016 further clarifies that there is a strong growing trend in luxury goods in countries like China, particularly the growing demand in luxury cars, hospitality and beauty luxury goods.

\section{Literature Review}

\subsection{Repeat Purchase Intention}

A consumer typically decides to undergo a repeat purchase when he/she is normally satisfied with the brand and is in the last stage of post purchase behaviour of the consumer buying process (Kotler \& Armstrong, 2016). The consumer reviews the brand's experience he/she had during the product's or service's use. Therefore, repeat purchase intention actually takes place in the buyer's 'black box' when the consumer has decided whether to purchase the same brand or not. However, Jones \& Sasser (1995) argue that consumers should possess both high satisfaction and loyalty towards the brand, in order to become the brand's loyalist or apostle. Therefore, repeat purchase intention can serve as a predictor for the actual purchase behaviour. Companies are now more interested in maintaining customer' repeat purchase because it will not only lead to sustained competitive advantage, but it will help increase profitability against fierce competition whilst decreasing new costs in attracting new consumers as well (Kuo, Hu, \& Yang, 2013; Reichheld \& Sasser, 1990). For example, according to Reichheld \& Sasser (1990), a company's profits could increase by $25 \%$ to $85 \%$ with a mere $5 \%$ increase in consumer retention. On the contrary, the same company can incur 5 times more cost in attracting new consumers.

Researchers have studied many factors that affect repeat purchase intention (Table 1). As stated below, some of the variables include Convenience, Hedonic Value, Perceived Risk, Customer Satisfaction, Consumer Inertia, Positive word-of-mouth, Value, Trust, Habit, Familiarity, Product Attribute, Luxury Value, and Social Influence. These studies were carried out on different samples, topics and locations, and the influences varied among different papers. For example, research by Kuo, Hu \& Yang (2013) reveals that consumer inertia has more influence than satisfaction among female online shoppers for repeat purchase, which is contrary to Jones \& Sasser (1995)'s argument that consumers generally have high satisfaction and loyalty when they intend to repeat purchase. Since this research focusses on the determinants of hedonic value, satisfaction, consumer inertia and product attribute on the repeat purchase intention of luxury brands, the following sections will provide a literature review of Hedonic Value, Satisfaction, Consumer Inertia and Product Attributes.

Table 1. Prior Literature on Repeat Purchase

\begin{tabular}{|c|c|c|c|c|c|}
\hline Research & Context & Dependent Variable & (s) & Independent Variable(s) & Key Findings \\
\hline $\begin{array}{l}\text { Chiu et al. } \\
(2012)\end{array}$ & $\begin{array}{l}\text { Online } \\
\text { Auction }\end{array}$ & $\begin{array}{l}\text { Repeat Purchase } \\
\text { (RPI) }\end{array}$ & Intention & $\begin{array}{l}\text { Trust (TRT), Value (VAL), Familiarity } \\
(\text { FAM), Satisfaction (SAT), Habit (HAB) }\end{array}$ & $\begin{array}{l}\mathrm{TRT} \rightarrow \mathrm{RPI} \\
\mathrm{HAB} \rightarrow \mathrm{RPI}\end{array}$ \\
\hline $\begin{array}{l}\text { Chiu et al. } \\
(2014)\end{array}$ & E commerce & $\begin{array}{l}\text { Repeat Purchase } \\
\text { (RI) }\end{array}$ & Intention & $\begin{array}{l}\text { Utilitarian Value (UV), Hedonic Value (HV), } \\
\text { Perceived Risk (PR) }\end{array}$ & $\begin{array}{l}\mathrm{UV} \rightarrow \mathrm{RPI} \\
\mathrm{HV} \rightarrow \mathrm{RPI} \\
\mathrm{PR} \rightarrow \mathrm{RPI}\end{array}$ \\
\hline $\begin{array}{l}\text { Goh et al. } \\
(2016)\end{array}$ & $\begin{array}{l}\text { Smartphone } \\
\text { shopping }\end{array}$ & $\begin{array}{l}\text { Repeat Purchase } \\
\text { (RPI) }\end{array}$ & Intention & $\begin{array}{l}\text { Product Attribute (PA), Luxury Value (LV), } \\
\text { Consumer Inertia (CI) }\end{array}$ & $\begin{array}{l}\mathrm{PA} \rightarrow \mathrm{RPI} \\
\mathrm{LV} \rightarrow \mathrm{RPI} \\
\mathrm{CI} \rightarrow \mathrm{RPI}\end{array}$ \\
\hline $\begin{array}{l}\text { Gupta \& Kim } \\
(2007)\end{array}$ & $\begin{array}{l}\text { Online Book } \\
\text { Store }\end{array}$ & Repurchase Intentic & n (RI) & $\begin{array}{l}\text { Convenience (CON), Pleasure } \\
\text { Perceived price (PP), Perceived } \\
\text { Transaction experience }(\mathrm{TE})\end{array}$ & $\begin{array}{l}\mathrm{PV} \rightarrow \mathrm{RI} \\
\mathrm{PP} \rightarrow(-) \mathrm{RI} \\
\mathrm{CON} \rightarrow \mathrm{RI} \\
\mathrm{PLE} \rightarrow \mathrm{RI}\end{array}$ \\
\hline $\begin{array}{l}\text { Hsu, Chang \& } \\
\text { Chuang (2015) }\end{array}$ & $\begin{array}{l}\text { Online } \\
\text { shopping }\end{array}$ & $\begin{array}{l}\text { Repeat Purchase } \\
\text { (RPI) }\end{array}$ & Intention & $\begin{array}{l}\text { Confirmation (CON), Perceived Value (PV), } \\
\text { Website Quality (WQ), Satisfaction (SAT), } \\
\text { Trust (TRT) }\end{array}$ & $\begin{array}{l}\mathrm{TRT} \rightarrow \mathrm{RPI} \\
\mathrm{SAT} \rightarrow \mathrm{RPI} \\
\mathrm{PV} \rightarrow \mathrm{RPI}\end{array}$ \\
\hline $\begin{array}{l}\text { Khalifa \& Liu } \\
(2007)\end{array}$ & $\begin{array}{l}\text { Online } \\
\text { Shopping }\end{array}$ & Repurchase Intentic & n (RI) & $\begin{array}{l}\text { Perceived usefulness (PU), online shopping } \\
\text { satisfaction (SAT), online repurchase habit } \\
\text { (HAB), online Repurchase experience (EXP) }\end{array}$ & $\begin{array}{l}\mathrm{PU} \rightarrow \mathrm{RI} \\
\mathrm{SAT} \rightarrow \mathrm{RI}\end{array}$ \\
\hline $\begin{array}{l}\text { Kim \& Gupta } \\
(2009)\end{array}$ & $\begin{array}{l}\text { Online book } \\
\text { store }\end{array}$ & Purchase Intention & (PI) & $\begin{array}{l}\text { Perceived risk }(\mathrm{PR}) \text {, perceived price }(\mathrm{PP}) \text {, } \\
\text { perceived value }(\mathrm{PV})\end{array}$ & $\begin{array}{l}\mathrm{PP} \rightarrow(-) \mathrm{PI} \\
\mathrm{PV} \rightarrow \mathrm{PI}\end{array}$ \\
\hline $\begin{array}{l}\text { Kuo, Hu \& } \\
\text { Yang }(2013)\end{array}$ & $\begin{array}{l}\text { Online } \\
\text { shopping }\end{array}$ & $\begin{array}{l}\text { Repeat Purchase } \\
\text { (RI) }\end{array}$ & Intention & Inertia (CI), Satisfaction (CS) & $\begin{array}{l}\mathrm{CI} \rightarrow \mathrm{RPI} \\
\mathrm{CS} \rightarrow \mathrm{RPI}\end{array}$ \\
\hline
\end{tabular}




\begin{tabular}{|c|c|c|c|}
\hline $\begin{array}{l}\text { Qureshi et al. } \\
(2009)\end{array}$ & $\begin{array}{l}\text { Online } \\
\text { shopping }\end{array}$ & Repurchasing Intention (RI) & $\begin{array}{l}\text { Perceived Website Quality (PWQ), perceived } \\
\text { capability of order fulfillment (PCOF), } \\
\text { reputation (REP), trust in vendor (TRT) }\end{array}$ \\
\hline
\end{tabular}

Note. $\rightarrow(-)$ indicates negative influence

\subsection{Product Attribute}

Product Attribute(s) can be a set of characteristics that define one particular brand, and consumers are able to recall the particular brand based on the product's attribute(s), thereby defining a consumer's consumption experience (Costley \& Bruks, 1992; Smith \& Deppa, 2009). The attributes of any brand can also be seen as 'dimensions of brand personalities', for example, Aaker (1997) defined the 5 brand personalities as Sincerity, Excitement, Competence, Sophisticated and Ruggedness. Consumers also tend to evaluate their brand's experience with these brand personalities in order to adopt a repeat purchase intention. Aaker (1997) further explained that each brand dimension has correlated with some brand personalities: Sincerity dimension correlates with attributes of honesty, cheerfulness, wholesomeness and down-to-earth personalities. Excitement dimension correlates with a brand's attribute representing imagination, spirited, daring, and up-to-date personalities. Similarly, Competence correlates with reliability, success, and intelligence, while Ruggedness personality correlates with attributes like a brand being outdoorsy and tough. Furthermore, Aaker's brand testing samples included luxury hotels and clothing. However, these dimensions are only used for literature review for better understanding of past researches and its relation with repeat purchase intention.

According to Anderson \& Mittal (2000), there is a dependent link between how well the product attributes perform against customer satisfaction, thereby enhancing customer experience and likely leading to a repeat purchase. Product attributes are one of the important element used by consumers to evaluate their product of choice (Zhang et al., 2002). This evaluation is supported by Tom et al. (1987)'s research in which product attributes are used as a basis of evaluation regarding purchase intention. Product Attribute has mostly been an important indicator for a consumer's purchase intention. Studies like Wee, Ta \& Cheok (1995) find that Product Attributes affect consumer purchase intention, whereas Goh et al. (2016) find that product attribute is among positive influencers of repeat purchase intention. Some other studies done on product attributes in various contexts include research done by Huber, Herrmann \& Morgan (2001); Martin (1998); Min, Overby \& Im (2012); Rahman, Zhu \& Liu (2008). Therefore, different product attribute impacts differently in the consumer's mind, but it is overall affecting the repeat purchase in different contexts.

\subsection{Consumer Inertia}

In a nutshell, consumer's inertia is an assumption that many consumers are inclined to stick to the same brand's consumption unless they are convinced there is a good reason to switch to other brand, also known as energy threshold or called as 'status quo bias' by behavioural economists (Castella, 2011). Prof Mazzucato (cited in Castella, 2011) believes that consumer experts have a misconception that consumers behave rationally at all times and have the benefit of 'perfect information', but in reality, consumers happily stick to their chosen products or services which becomes their routine and inertia sets in due to both the costs of acquiring new information and the costs of switching has become a psychological barrier for them.

Inertia-driven consumers make purchasing intentions without much contemplation (Solomon, 2013). Inertia-driven consumers, therefore, unconsciously support the repeat purchasing of the same brands based on their past consumption experience (Gulati, 1995; Oliver, 1999; Solomon, 2013). Past studies test that consumer inertia could drive consumer to repeat purchase (Goh et al., 2016; Huang \& Yu, 1999; Kuo, Hu \& Yang, 2013; Liu et al., 2007, cited in Goh et al., 2016; White \& Yanamandram, 2007). Therefore, consumer inertia has a positive effect on the repeat purchase as consumers will be more likely not to switch to other brands.

Some reasons that consumers develop inertia can be linked to familiarity, saving time and cost, and minimal difference between alternate brands (Anderson \& Srinivasan, 2003; Liu et al., 2007, cited in Goh et al., 2016; Oliver, 1999; Tsai \& Huang, 2007). Familiarity occurs when consumers get more and more familiar with the band by supporting it, in order to avoid uncertainty in choosing alternate brands. Some consumers are also reluctant to spend time and money to get accustomed to the new brands, thus developing inertia. The same reason goes for minimal differences in brand, where consumers tend to repeat their purchase unless there are noticeable differences in alternatives provided by competitors.

\subsection{Satisfaction}

Previous studies have used satisfaction as one of the important independent variables for repeat purchase intention (Chiu et al., 2012; Goh et al., 2016; Kuo, Hu \& Yang, 2013). Satisfaction occurs when the consumer is 
content with the brand's consumption. A consumer is more likely to return and repeat his/her purchase of the same brand if he/she is satisfied with its consumption (Kuo, Hu \& Yang, 2013; Lee, Choi \& Kang, 2009). Similarly, satisfaction gained in the post-purchase stage of consumer buying behaviour will positively enhance consumer's attitude towards the brand, thereby increasing odds of undergoing a repeat purchase (Engel, Fries \& Singer, 2001). For marketers, keeping their consumers satisfied is both challenging and important. This is because satisfied consumers are less attracted by competitors, are more likely to try additional product accessories (product depth) and other brands (product width) of the same company, and are not likely affected by price changes (Hansemark \& Albinsson, 2004; Kotler \& Armstrong, 2016; Zineldin, 2000). Furthermore, consumers from emerging markets are now considered as 'Global Citizens', i.e., consumers seeing the global success of luxury brands as a signal of quality, prestige, wealth, status, and uniqueness, and are willing to pay the premium price charged by these luxury brands, once they are satisfied (both by physical and psychographic pleasures) (Belk, 1988, cited in Goh et al., 2016; Bian \& Forsythe, 2012; Li, Robson \& Coates, 2013; Solomon et al., 2016). Also, most emerging market consumers' satisfaction is justified by the brand's value as it displays a consumer's high living standard and status against their social classes (Tsai, 2005).

However, it should be noted that satisfaction and loyalty go hand in hand, meaning that even if the consumer's satisfaction level is high, the consumer may have low brand commitment (mercenary) and he/she may switch back and forth from current brand to a competitor's brand (Jones \& Sasser, 1995). It can be further elaborated that once a consumer is satisfied, he/she will start to believe that the company surpasses its competition by understanding, listening and addressing his/her needs, wants, values, etc. which will subsequently lead to the consumer being highly loyal to the brand (Jones \& Sasser, 1995).

Based on past and current studies, it can be concluded that, Satisfaction will positively influence repeat purchase intention, especially for determining long-term repeat purchase (Brady, Robertson \& Cronin, 2001; Cronin, Brady \& Hult, 2000; Johnson \& Fornell, 1991; Ranaweera \& Prabhu, 2003; Zeithaml, Berry \& Parasuraman, 1996).

\subsection{Hedonic Value}

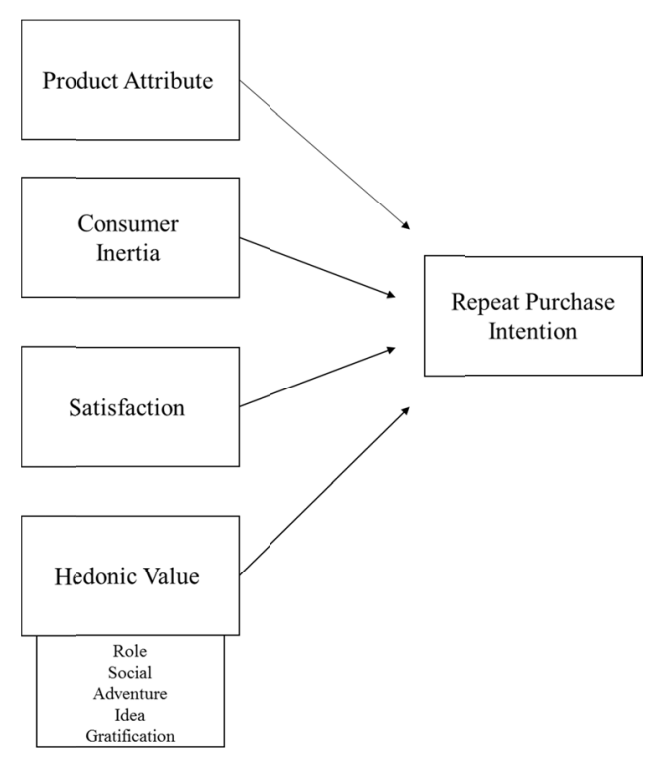

Figure 1. Conceptual Research Framework

Hedonic value can be defined as the pleasure consumers experience during a product's or service's consumption that relates to aspects of fun, playfulness, multisensory, fantastic and emotions (Babin, Darden \& Griffin, 1994; Hirschman \& Holbrook, 1982). For further understanding hedonism, Arnold \& Reynold (2003) proposed that there are 6 different dimensions of hedonic drives regarding consumers' shopping motives, they are hedonic Value (feeling joyful after getting discounted value, bargain, etc. on price), Role (enjoyment gained by shopping for others), Social (enjoyment in shopping with social groups, such as friends or family), Adventure (décor and visuals, etc. of store giving stimulation of great shopping experience), Idea (shopping to keep up with latest fashion trends, etc.), and Gratification (shopping to relieve stress, for good mood, treating oneself, etc.). These dimensions have been empirically confirmed under hedonism against repeat purchase intention in studies like Chiu et al., 2014. Hedonic value has been used as one of the important independent variables in numerous 
studies (for example: Chiu et al., 2012; Shukla \& Purani, 2012; Shunmugam, 2015 for dependent variables repeat purchase intention, luxury purchase intention, and purchase intention respectively).

Therefore, it can be argued that hedonic value is one of the main drivers of repeat purchase intention (Kim \& Gupta, 2009; Lin, Sher \& Shih., 2005). Past studies also confirm that importance of various hedonic values enable the drive to loyalty and repeat purchase (Chiu et al., 2014; Jones, Reynolds \& Arnold, 2006; Overby \& Lee, 2006) thus hedonic value will positively influence repeat purchase intention.

Based on the literature review on the study variables, a research framework has been developed (Figure 1) that shows the relationship between independent variables with the dependent variable.

\section{Method}

\subsection{Design}

Convenience sampling was used as the quantitative data collection type, mostly comprising of students since the researcher's sample location was around the University locality. Although the minimum sample size for convenience sampling is 100 , sample size of 140 was finalised as it was suitable for fulfilling the research objectives (Saunders, Lewis \& Thornhill, 2012). Furthermore, the sampling design is non-probability convenience sampling because it requires very low cost, is extensively used, and there is no need of full population list (Harvard Research Methods, n.d.; Saunders, Lewis \& Thornhill, 2012; Zikmund et al., 2009).

For the purpose of data collection, closed-ended questionnaires were designed since this is a quantitative study. Therefore, the sources required to construct a 5-point Likert scale questionnaire (Strongly Disagree, Disagree, Neutral, Agree, and Strongly Agree) were adapted from past literature (Table 2). Data collection took 1 month to complete and a combination of online and drop \& pick methods were used in and around the university campus area. The questionnaire consisted of 44 questions divided into 7 sections. Section A measured responses regarding the respondents' luxury purchase (such as favourite brand(s), purchase frequency, annual spending, etc.). As such, the questionnaire was scoped to 8 luxury brands, namely, Gucci, Chanel, Prada, Rolex, Ralph Lauren, Louis Vuitton, Cartier and Coach. Section B consisted of demography related questions (such as age, gender, income, nationality, etc.). Lastly, sections $\mathrm{C}$ to $\mathrm{G}$ consisted of questions related to the research variables of this study, which were sourced from various past authors' questionnaires.

\subsection{Instrumentation}

As seen from table 2 below, repeat purchase intention was sourced from Tsai \& Huang (2007), which has 4 questions. Satisfaction was also adapted from Tsai \& Huang (2007), which has 4 questions. Both hedonic value along with its dimensions, have been sourced from Arnold \& Reynold (2003), which has a total of 18 questions. Consumer Inertia questions were adapted from Anderson \& Srinivasan (2003) which has 3 questions. Finally, product attribute questions were sourced from Goh et al. (2016), which has 3 questions.

In order for the above mentioned questionnaires to be valid and reliable, Cronbach alpha with a minimum value of 0.7 is required for a questionnaire to be accepted (Fornell \& Larcker, 1981). As such, the Cronbach alpha of the questionnaires from all the above mentioned sources are well above 0.7 , meaning that they are reliable, valid and suitable sources for developing the questionnaire for this research in order to measure appropriate responses from the target subjects.

Table 2. Instrumentation

\begin{tabular}{cccc}
\hline Variable/Construct & Author Source(s) & Number of questions & Cronbach Alpha $^{*}$ \\
\hline Repeat Purchase Intention ${ }^{+}$ & Tsai \& Huang (2007) & 4 & 0.96 \\
Satisfaction & Tsai \& Huang (2007) & 4 & 0.93 \\
& & Hedonic Value: 3 & 0.87 \\
& & D1-Gratification: 3 & 0.77 \\
Hedonic Value + 5 Dimensions & Arnold \& Reynold (2003) & D2-Role:3 & 0.84 \\
& & D3-Adventure:3 & 0.86 \\
Consumer Inertia & D4-Social:3 & 0.83 \\
Product Attribute & Anderson \& Srinivasan (2003) & D5-Idea:3 & 0.87 \\
\hline
\end{tabular}

Note. ${ }^{+}$Dependent Variable Type; ${ }^{*}$ Cronbach Alpha should be more than 0.7 , in order for the questionnaires to be valid and reliable (Fornell \& Larcker, 1981) 


\subsection{Respondent Profile}

134 responses have been received $(73.10 \%$ males and $26.90 \%$ females) in this study from Kuala Lumpur region. Table 3 below shows that the majority of respondents were single Malay male university students below 24 years of age. The sample belongs to the generation $\mathrm{Y}$ age-group cohort.

Table 3. Respondent Demographics Summary

\begin{tabular}{|c|c|c|c|}
\hline Variable & Category & Frequency & Percentage \\
\hline \multirow{2}{*}{ Gender } & Male & 95 & 73.10 \\
\hline & Female & 35 & 26.90 \\
\hline \multirow{6}{*}{ Age Group } & Below 20 years & 28 & 21.50 \\
\hline & 20-24 years & 60 & 46.20 \\
\hline & $25-29$ years & 19 & 14.60 \\
\hline & $30-34$ years & 19 & 14.60 \\
\hline & 35 years and above & 4 & 3.10 \\
\hline & Single & 98 & 76.00 \\
\hline \multirow{2}{*}{ Marital Status } & Married & 29 & 22.50 \\
\hline & Divorced & 2 & 1.60 \\
\hline \multirow{5}{*}{ Ethnicity } & Arab & 4 & 3.80 \\
\hline & Chinese & 16 & 15.20 \\
\hline & Indian & 17 & 16.20 \\
\hline & Malay & 68 & 64.80 \\
\hline & Secondary School & 19 & 15.20 \\
\hline \multirow{3}{*}{ Highest Qualification Level } & Diploma & 21 & 16.80 \\
\hline & Tertiary Level & 74 & 59.20 \\
\hline & Post Graduate & 11 & 8.80 \\
\hline \multirow{2}{*}{ Occupation } & Students & 106 & 79.10 \\
\hline & Non-Students & 28 & 20.90 \\
\hline \multirow{3}{*}{ Monthly Income Level } & Less than RM 2,000 & 63 & 48.50 \\
\hline & RM 2,000-4,000 & 27 & 20.80 \\
\hline & RM 4,001 and Above & 40 & 30.80 \\
\hline
\end{tabular}

Table 4 below is a descriptive analysis of the data gathered from the respondents, which is represented in row percentage

Table 4. Itemised Questions for Research Variables in Row Percentage

\begin{tabular}{|c|c|c|c|c|c|c|}
\hline Item & Statement & $\begin{array}{l}\text { Strongly } \\
\text { Disagree }\end{array}$ & Disagree & Neutral & Agree & $\begin{array}{l}\text { Strongly } \\
\text { Agree }\end{array}$ \\
\hline HV 1 & To me, shopping is an adventure & 3.20 & 16.70 & 21.40 & 38.10 & 20.60 \\
\hline HV 2 & I find shopping stimulating & 0.80 & 10.30 & 30.20 & 42.10 & 16.70 \\
\hline HV 3 & Shopping makes me feel like I am in my own universe & 5.60 & 15.90 & 25.40 & 37.30 & 15.90 \\
\hline HV 4 & When I'm in a down mood, I go shopping to make me feel better & 11.10 & 20.60 & 18.30 & 31.00 & 19.00 \\
\hline HV 5 & To me, shopping is a way to relieve stress & 11.90 & 15.10 & 15.90 & 38.90 & 18.30 \\
\hline HV 6 & I go shopping when I want to treat myself to something special & 4.00 & 7.10 & 15.90 & 42.90 & 30.20 \\
\hline HV 7 & I like shopping for others because when they feel good I feel good & 7.90 & 15.10 & 19.00 & 34.90 & 23.00 \\
\hline HV 8 & I enjoy shopping for my friends and family & 4.00 & 7.10 & 17.50 & 38.90 & 32.50 \\
\hline HV 9 & I enjoy shopping around to find the perfect gift for someone & 2.40 & 11.10 & 14.30 & 38.10 & 34.10 \\
\hline HV 10 & For the most part, I go shopping when there are sales & 1.60 & 4.80 & 8.70 & 42.90 & 42.10 \\
\hline HV 11 & I enjoy looking for discounts when I shop & 1.60 & 2.40 & 10.30 & 42.10 & 43.70 \\
\hline HV 12 & I enjoy hunting for bargains when I shop & 3.20 & 9.50 & 19.80 & 39.70 & 27.80 \\
\hline HV 13 & I go shopping with my friends or family to socialise & 4.00 & 8.7 & 18.30 & 43.70 & 25.40 \\
\hline HV 14 & I enjoy socialising with others when I shop & 6.30 & 11.90 & 19.80 & 36.50 & 25.40 \\
\hline HV 15 & Shopping with others is a bonding experience & 7.90 & 7.10 & 17.50 & 46.80 & 20.60 \\
\hline
\end{tabular}




\begin{tabular}{|c|c|c|c|c|c|c|}
\hline HV 16 & I go shopping to keep up with the trends & 10.30 & 8.70 & 19.80 & 37.30 & 23.80 \\
\hline HV 17 & I go shopping to keep up with the new fashions & 9.50 & 9.50 & 19.00 & 39.70 & 22.20 \\
\hline HV 18 & I go shopping to see what new products are available & 4.00 & 7.10 & 15.10 & 49.20 & 24.60 \\
\hline S 1 & In general, the purchase of luxury brands meet my expectations & 6.50 & 7.30 & 16.90 & 50.00 & 19.40 \\
\hline S 2 & Overall, luxury brands are good products to purchase with & 3.20 & 6.50 & 16.90 & 54.00 & 19.40 \\
\hline S 3 & My choice to purchase luxury items was a wise one & 2.40 & 8.10 & 21.80 & 52.40 & 15.30 \\
\hline CI 1 & $\begin{array}{l}\text { Unless I became very dissatisfied with luxury brands, switching to } \\
\text { a new substitute would be a bother }\end{array}$ & 11.40 & 17.10 & 22.80 & 35.00 & 13.80 \\
\hline CI 2 & I would find it difficult to stop purchasing luxury brands & 26 & 16.30 & 26.80 & 21.10 & 9.80 \\
\hline CI 3 & $\begin{array}{l}\text { For me the cost in time, money, and effort to change luxury brands } \\
\text { is high }\end{array}$ & 13.00 & 22.00 & 17.10 & 30.10 & 17.90 \\
\hline PA 2 & $\begin{array}{l}\text { I chose luxury brands because it provides excellent store and } \\
\text { customer service experience }\end{array}$ & 6.50 & 11.40 & 22.00 & 37.40 & 22.80 \\
\hline PA 3 & $\begin{array}{l}\text { I chose luxury brands because the brands are up-to-date with latest } \\
\text { fashion trends }\end{array}$ & 6.50 & 13.80 & 16.30 & 41.50 & 22.00 \\
\hline RPI 1 & I consider myself a loyal patron of luxury brands & 12.80 & 16.80 & 19.20 & 36.00 & 15.20 \\
\hline RPI 2 & I will do more purchases with luxury products in the near future & 7.20 & 13.60 & 25.60 & 38.40 & 15.20 \\
\hline RPI 3 & I consider luxury brands as my first choice for shopping & 16.00 & 14.40 & 17.60 & 33.60 & 18.40 \\
\hline RPI 4 & $\begin{array}{l}\text { I intend to purchase luxury brands again sometime during the next } \\
2 \text { weeks }\end{array}$ & 17.60 & 24.00 & 18.40 & 28.00 & 12.00 \\
\hline
\end{tabular}

\subsection{Data Analysis}

Descriptive and inferential analyses were carried out to achieve research objectives. The research analysis was scoped to relationship testing. As such, correlation and linear regression modelling tests were carried out using SPSS software. Preliminary tests such as normality, data reliability and validity tests were conducted before proceeding to relationship testing. This was done to ensure the data collected from respondents through questionnaires were reliable enough to proceed to the data analysis stage. The findings of the study are interpreted and discussed in the following section.

\section{Results}

Table 5 below shows the linear regression modelling of the independent variables of Product Attribute (PA), Satisfaction (S), Consumer Inertia (CI), Hedonic Value (HV) against the dependent variable Repeat Purchase Intention (RPI).

Table 5. Summary of Multiple (Linear) Regression Analyses for Repeat Purchase Intention

\begin{tabular}{|c|c|c|c|c|c|}
\hline Variables & Unstandardised Coefficients & & Standardised Coefficients & $\mathrm{t}$ & Sig. \\
\hline & B & Std. Error & Beta & & \\
\hline (Constant) & -1.649 & 0.532 & & -3.100 & 0.002 \\
\hline Overall Hedonic Value & 0.584 & 0.125 & 0.339 & 4.655 & 0.000 \\
\hline Satisfaction & 0.709 & 0.108 & 0.484 & 6.562 & 0.000 \\
\hline Consumer Inertia & 0.012 & 0.082 & 0.012 & 0.149 & 0.882 \\
\hline Product Attribute & -0.007 & 0.088 & -0.006 & -0.080 & 0.937 \\
\hline
\end{tabular}

Note. Adjusted R square $=0.460 ; \mathrm{df}=4 ; \mathrm{F}=26.987 ; \mathrm{p}=0.000$

As seen from table 5 above, firstly, the significance model is represented as $F(4,118)=26.987, p=0.000$. The result is significant as p value is well below 0.05 . In other words, these values (independent variables) are good predictors of the outcome variable RPI. Secondly, $46 \%$ of the variance in HVO, S, CI and PA can be explained by one's level of RPI (from adjusted R square of 0.460). Finally, the unstandardised regression coefficients values (Beta slope) can be used to explain the graphical line (of equation $\mathrm{y}=\mathrm{mx}+\mathrm{b}$ ) that uses independent variables to predict RPI (Pallant, 2010). Therefore, the regression model for RPI is: repeat purchase intention $=$ 
0.584 overall hedonic value +0.709 satisfaction +0.012 consumer inertia $+(-0.007)$ product attribute $+(-1.649)$.

Among the four predictor variables, only two variables of overall hedonic value and satisfaction were found to have significance towards repeat purchase intention (at 0.000 levels). As such, 0.339 and 0.484 were the standardised coefficients (Beta) found for overall hedonic value and satisfaction respectively. Thereof, satisfaction has a more stronger and positive correlation (and a stronger predictor) of repeat purchase intention $(0.484>0.339)$. It is also worth mentioning that consumer inertia has no correlation and is a very weak predictor of repeat purchase, and product attribute shows a weak and negative correlation with repeat purchase intention.

Table 6 below has a separate regression model for the five dimensions of hedonic value. Therefore, the prediction level of dimensions on repeat purchase intention is analysed separately below.

Table 6. Dimension Variable Summary of Multiple (Linear) Regression Analyses for Repeat Purchase Intention

\begin{tabular}{|c|c|c|c|c|c|}
\hline Variables & Unstandardised Coefficients & & Standardised Coefficients & $\mathrm{t}$ & Sig. \\
\hline & B & Std. Error & Beta & & \\
\hline (Constant) & 0.344 & 0.466 & & 0.740 & 0.461 \\
\hline Adventure & 0.022 & 0.108 & 0.107 & 0.207 & 0.837 \\
\hline Gratification & 0.177 & 0.123 & 0.159 & 1.445 & 0.151 \\
\hline Role & 0.049 & 0.110 & 0.041 & 0.443 & 0.658 \\
\hline Social & 0.042 & 0.103 & 0.037 & 0.407 & 0.685 \\
\hline Idea & 0.497 & 0.106 & 0.449 & 4.688 & 0.000 \\
\hline
\end{tabular}

Note. Adjusted R square $=0.347 ; \mathrm{df}=5 ; \mathrm{F}=14.176 ; \mathrm{p}=0.000$

As seen from table 6 above, the significance model is represented as $F(5,119)=14.176, p=0.000$. The result is significant as $\mathrm{p}$ value is well below 0.05 . Therefore, the dimension values of hedonic value are also good predictors of the outcome variable RPI. $34.70 \%$ of the variance in these five dimensions can be explained by one's level of RPI. Therefore, the regression model for the dimensions is: repeat purchase intention $=0.022$ adventure +0.177 gratification +0.049 role +0.042 social +0.497 idea +0.344 .

Among these five predictor dimension variables of $\mathrm{HV}$, only one variable of idea was found to have significance towards repeat purchase intention (at 0.000 level). As such, 0.449 is the standardised coefficients (Beta) for this dimension. It can also be argued that the idea dimension of hedonic value is a stronger predictor than the overall hedonic value itself $(0.449>0.339)$. However, since the inter-variable analysis is out of the scope of this research, it can be concluded from table 6 that only idea dimension is a significant predictor of RPI.

To summarise, the more product attributes or features luxury brands may have to offer, the less people are willing to repeat their consumption. Similarly, consumer inertia has no effect on the repeat purchase of luxury brands as consumers may find it easy and convenient to switch to other brands without much effort. Furthermore, a consumer who is satisfied and experiences hedonic values (including idea values such as new fashion trends and styles) towards luxurious consumptions, are most likely to repeat purchase as luxurious consumption is often associated with material and psychological benefits.

\section{Conclusion and Recommendations}

The current research of Chiu et al. (2012), Chiu et al. (2014), Goh et al. (2016), and Kuo, Hu \& Yang (2013) has sparked particular interest for this study to pursue the repeat purchase intention for luxury brands. The common theme for these studies is the repeat purchase intention. However, the antecedents, study location and research topic differed. Most of the studies relating to luxury brands have been in relation with purchase and repeat purchase intentions towards consumer buying behaviour in various locations. However, very little research is done on the repeat purchase intention, particularly on luxury brands in the Malaysia region (Table 1). For example, research done by Goh et al. (2016) have studied on the impact of consumer inertia, product attribute, satisfaction, and social influence on the repeat purchase intention among Malaysian consumers, but it is focussed on the smartphone market.

The purpose of this study was to investigate the repeat purchase intention of luxury brands among generation $\mathrm{Y}$ consumers in Malaysia. The findings indicate that satisfaction and hedonic value have strong correlation with repeat purchase intention, satisfaction being the strongest predictor for consumers in Malaysia. Although majority of the respondents were Malay university students belonging to the generation $\mathrm{Y}$ age group, the results may not be a true representation of the entire population because of the convenience sample methodology that was limited to Kuala Lumpur location. Future research is recommended that can use a more precise data 
collection technique (such as random sampling, etc.) that could further enhance the data findings.

The research findings will enable luxury brand companies to better understand what motivates consumers in Malaysia to repeat luxury purchases from them. Firstly, marketers should understand that keeping their customers satisfied and fulfilling their hedonistic needs are important factors to motivate the consumers to continue to repeat their purchases with luxury brands. Secondly, since celebrity endorsements and advertisements also increase the likelihood to repeat purchase, marketers should continue their marketing campaigns accordingly to not only enhance repeat purchase and loyalty, but to attract new customers as well. Finally, marketers must keep their luxury brands trendy, up-to-date and fashionable for better brand positioning, and in order to maintain current customer base.

This study has aimed to bridge the gap between luxury and repeat purchase fields in Malaysia, and has found that satisfaction and hedonic value plays a key role in the minds of consumers to repeat their luxury consumption. However, it is recommended for researchers to further investigate the correlations of other variables in this study to confirm or contradict these findings. They may do so by testing these on other larger sample locations or with other brands or in other topics as well. Furthermore, researchers can use other variables to test the psychological impact on the consumers' luxurious consumption, be it a single or repeated purchase. Finally, researchers can use other data measuring methods (such as qualitative analysis, random sampling, etc.) to get a more precise and detailed analysis in luxury field. Furthermore, researchers can test the effect and impact of these variables on the repeat purchase intention, because this study has only tested the relationships between independent variables with depend variable.

Finally, this is a quantitative and descriptive research that is limited to the scope of the generation Y consumers' luxury repeat purchase intention in Malaysia. Data was collected through closed-ended questionnaires by means of convenience sampling. As such, it is recommended for future researchers to use more precise data collection techniques and on a larger sample to get further insights on the consumer behaviour in Malaysia.

\section{Acknowledgements}

I would like to express my gratitude to Associate Professor Dr. Benjamin Chan Yin-Fah for encouraging me to convert part of my dissertation into this paper. I would also like to thank Staffordshire University, UK for providing me the necessary online resources for research purposes. Finally, I would like to dedicate this paper to my loving family and friends, and the respondents who have provided valuable feedback and support to make this research possible.

\section{References}

Aaker, J. (1997). Dimensions of Brand Personality. Journal of Marketing Research, 34(3), 347-356. https://doi.org/10.2307/3151897

Anderson, E. \& Mittal, V. (2000). Strengthening the Satisfaction-Profit Chain. Journal of Service Research, 3(2), 107-120. https://doi.org/10.1177/109467050032001

Anderson, R., \& Srinivasan, S. (2003). E-satisfaction and e-loyalty: A contingency framework. Psychology and Marketing, 20(2), 123-13. https://doi.org/10.1002/mar.10063

Arnold, M. \& Reynold, K. (2003). Hedonic shopping motivations. Journal of Retailing, 79(2), 77-95. https://doi.org/10.1016/S0022-4359(03)00007-1

Babin, B., Darden, W. \& Griffin, M. (1994). Work and/or Fun: Measuring Hedonic and Utilitarian Shopping Value. Journal of Consumer Research, 20(4), 644-656. https://doi.org/10.1086/209376

Bian, Q., \& Forsythe, S. (2012). Purchase intention for luxury brands: A cross cultural comparison. Journal of Business Research, 65(10), 1443-1451. https://doi.org/10.1016/j.jbusres.2011.10.010

Brady, M., Robertson, C. \& Cronin, J. (2001). Managing behavioral intentions in diverse cultural environments: an investigation of service quality, service value, and satisfaction for American and Ecuadorian fast-food customers. J. of International Management, 7(2), 129-149. https://doi.org/10.1016/S1075-4253(00)00041-7

Castella, T. (2011). Energy switching: Why the customer inertia? - BBC News. Retrieved from $\mathrm{http}: / / \mathrm{www} . b b c . c o m /$ news/magazine-14989860

Chiu, C., Hsu, M., Lai., H, \& Chang, C. (2012). Re-examining the influence of trust on online repeat purchase intention: The moderating role of habit and its antecedents. Decision Support System, 53(4), 835-845. https://doi.org/10.1016/j.dss.2012.05.021

Chiu, C., Wang, E., Fang, Y. and Huang, H. (2014) .Understanding customers' repeat purchase intentions in B2C 
e-commerce: the roles of utilitarian value, hedonic value and perceived risk. Information Systems Journal, 24(1), 85-114. https://doi.org/10.1111/j.1365-2575.2012.00407.x

Colson, T. (2016). The top 9 luxury brands in the world - Business Insider. Retrieved from http://www.businessinsider.my/the-top-9-luxury-brands-in-the-world-2016-9

Costley, C. \& Brucks, M. (1992). Selective Recall and Information Use in Consumer Preferences. Journal of Consumer Research, 18(4), 464-474. https://doi.org/10.1086/209274

Cronin, J., Brady, M. \& Hult, G. (2000). Assessing the effects of quality, value, and customer satisfaction on consumer behavioral intentions in service environments. Journal of Retailing, 76(2), 193-218. https://doi.org/10.1016/S0022-4359(00)00028-2

D'Arpizio, C., Levato, F., Zito, D. \& Montgolfier, J. (2015). Luxury Goods Worldwide Market Study. Retrieved from http://www.bain.com/Images/BAIN_REPORT_Global_Luxury_2015.pdf

D'Arpizio, C., Levato, F., Zito, D. \& Montgolfier, J. (2016). Luxury Goods Worldwide Market Study, Fall-Winter 2016 - Bain \& Company. Retrieved from http://www.bain.com/publications/articles/luxury-goods-world wide-market-study-fall-winter-2016.aspx

David, W. \& Chiari, C. (2008). Keeping Luxury Inaccessible European School of Economics. MPRA Paper No. 11373.

Engel, A., Fries, P. \& Singer, W. (2001). Dynamic predictions: Oscillations and synchrony in top-down processing. Nature Reviews Neuroscience, 2(10), 704-716. https://doi.org/10.1038/35094565

Fornell, C. \& Larcker, D. (1981). Evaluating structural equation models with unobservable and measurement error. Journal of Marketing Research, 18(1), 39-50. https://doi.org/10.2307/3151312

Goh, S., Jiang, N., Hak, M. \& Tee, P. (2016). Determinants of Smartphone Repeat Purchase Intention among Malaysians: A Moderation Role of Social Influence and a Mediating Effect of Consumer Satisfaction. International Review of Management and Marketing, 6(4), 993-1004.

Gulati, R. (1995). Does Familiarity Breed Trust? The Implications of Repeated Ties for Contractual Choice in Alliances. Academy of Management Journal, 38(1), 85-12. https://doi.org/10.2307/256729

Gupta, S. \& Kim, H. (2007). The moderating effect of transaction experience on the decision calculus in on-line repurchase. International Journal of Electronic Commerce, 12(1), 127-158. https://doi.org/10.2753/JEC1086-4415120105

Hansemark, O. \& Albinsson, M. (2004). Customer satisfaction and retention: The experiences of individual employees. Managing Service Quality: An International Journal, 14(1), 40-57. https://doi.org/10.1108/09604520410513668

Harvard Research Methods (n.d.). Research Methods: Some Notes to Orient You. Retrieved from https://isites.harvard.edu/fs/docs/icb.topic851950.files/Research\%20Methods_Some\%20Notes.pdf

Hirschman, E. \& Holbrook, M. (1982). Hedonic Consumption: Emerging Concepts, Methods and Propositions. Journal of Marketing, 46(3), 92-101. https://doi.org/10.2307/1251707

Hsu, M., Chang, C. \& Chuang, L. (2015). Understanding the determinants of online repeat purchase intention and moderating role of habit: The case of online group-buying in Taiwan. International Journal of Information Management, 35(1), 45-56. https://doi.org/10.1016/j.ijinfomgt.2014.09.002

Huang, M. \& Yu, S. (1999). Are consumers inherently or situationally brand loyal?-A set intercorrelation account for conscious brand loyalty and nonconscious inertia. Psychology and Marketing, 16(6), 523-544. https://doi.org/10.1002/(SICI)1520-6793(199909)16:6<523::AID-MAR5>3.0.CO;2-B

Huber, F., Herrmann, A. \& Morgan, R. (2001). Gaining competitive advantage through customer value oriented management. Journal of Consumer Marketing, 18(1), 41-53. https://doi.org/10.1108/07363760110365796

Johnson, M. \& Fornell, C. (1991). A framework for comparing customer satisfaction across individuals and product categories. Journal of Economic Psychology, 12(2), 267-286. https://doi.org/10.1016/0167-4870(91)90016-M

Jones, M., Reynolds, C. \& Arnold, M. (2006). Hedonic and utilitarian shopping value: Investigating differential effects on retail outcomes. Journal of Business Research, 59(9), 974-981. https://doi.org/10.1016/j.jbusres.2006.03.006

Jones, T., \& Sasser, W. (1995). Why Satisfied Customers Defect. Harvard Business Review, 73(6), 88-91. 
Juggessur, J. \& Cohen, G. (2009). Is fashion promoting counterfeit brands?. Journal of Brand Management, 16(5), 383-394. https://doi.org/10.1057/bm.2008.46

Khalifa, M. \& Liu, V. (2007). Online consumer retention: Contingent effects of online shopping habit and online shopping experience. European Journal of Information Systems, 16(6), 780-92. https://doi.org/10.1057/palgrave.ejis.3000711

Kim, H. \& Gupta, S. (2009). A comparison of purchase decision calculus between potential and repeat customers of an online store. Decision Support Systems, 47(4), 477-487. https://doi.org/10.1016/j.dss.2009.04.014

Kollewe, J. (2015). Global luxury goods market exceeds $€ 1$ tn | Business | The Guardian. Retrieved from https://www.theguardian.com/business/2015/oct/29/global-luxury-goods-market-exceeds-1 tn-euro

Kotler, P. \& Armstrong, G. (2016). Principles of Marketing. Global Edition, 16th edn, Pearson

Kuo, Y., Hu, T. \& Yang, S. (2013). Effects of inertia and satisfaction in female online shoppers on repeat purchase intention. Managing Service Quality: An International Journal, 23(3), 168-187. https://doi.org/10.1108/09604521311312219

Lee, H., Choi, S., \& Kang, Y. (2009). Formation of e-satisfaction and repurchase intention: Moderating roles of computer self-efficacy and computer anxiety. Expert Systems with Applications, 36(4), 7848-7859. https://doi.org/10.1016/j.eswa.2008.11.005

Li, N., Robson, A. \& Coates, N. (2013). Chinese consumers' purchasing: Impact of value and affect. Journal of Fashion Marketing and Management: An International Journal, 17(4), 486-508. https://doi.org/10.1108/JFMM-03-2013-0030

Lin, C., Sher, P. \& Shih, H. (2005). Past progress and future directions in conceptualizing customer perceived value. International Journal of Service Industry Management, 16(4), 318-336. https://doi.org/10.1108/09564230510613988

Lipovetsly, G. (2007). Il tempo del lusso (Time for Luxury). Palermo, Italy, Sellerio

Liu, F., Li, J., Mizerski, D. \& Soh, H. (2012). Self-congruity, brand attitude and brand loyalty: a study on luxury brands. European Journal of Marketing, 46 (7/8), 922-937. https://doi.org/10.1108/03090561211230098

Martin, C.L. (1998). Relationship marketing: A high - involvement product attribute approach. Journal of Product and Brand Management, 7 (1), 6-26. https://doi.org/10.1108/10610429810209700

Miller, K. \& Mills, M. (2012). Contributing clarity by examining brand luxury in the fashion market. Journal of Business Research, 65 (10), 1471-1479. https://doi.org/10.1016/j.jbusres.2011.10.013

Min, S., Overby, J. \& Im, K. (2012). Relationships between desired attributes, consequences and purchase frequency. Journal of Consumer Marketing, 29 (6), 423-435. https://doi.org/10.1108/07363761211259232

Okonkwo, U. (2009). The luxury brand strategy challenge. Journal of Brand Management, 16 (5-6), 287-289. https://doi.org/10.1057/bm.2008.53

Oliver, R. (1980). A Cognitive Model of the Antecedents and Consequences of Satisfaction Decisions. Journal of Marketing Research, 17 (4), 460-469. https://doi.org/10.2307/3150499

Oliver, R. (1999). Whence Consumer Loyalty?. Journal of Marketing, 63, 33-34. https://doi.org/10.2307/1252099

Overby, J. \& Lee, E. (2006). The effects of utilitarian and hedonic online shopping value on consumer preference and intentions. Journal of Business Research, 59(10-11), 1160-1166. https://doi.org/10.1016/j.jbusres.2006.03.008

Qureshi, I., Fang, Y., Ramsey, E., McCole, P., Ibbotson, P. \& Compeau, D. (2009). Understanding online customer repurchasing intention and the mediating role of trust - An empirical investigation in two developed countries. European Journal of Information Systems, 18(3), 205-222. https://doi.org/10.1057/ejis.2009.15

Pallant, J. (2010). SPSS Survival Manual: A Step by Step Guide to Data Analysis Using SPSS (4th ed.). McGraw Hill Education

Rahman, O., Zhu, X. \& Liu, W. (2008). A study of the pyjamas purchasing behaviour of Chinese consumers in Hangzhou, china. Journal of Fashion Marketing and Management: An International Journal, 12(2), 217 231. https://doi.org/10.1108/13612020810874890 
Ranaweera, C. \& Prabhu, C. (2003). On the relative importance of customer satisfaction and trust as determinants of customer retention and positive word of mouth. Journal of Targeting, Measurement and Analysis for Marketing, 12 (1), 82-90. https://doi.org/10.1057/palgrave.jt.5740100

Reichheld, F. \& Sasser, W. (1990). Zero defections: Quality comes to service. Harvard Business Review, 68 (5), 105-111.

Saunders, M., Lewis, P. \& Thornhill, A. (2012). Research Methods for Business Students (6th ed.). Pearson.

Shukla, P. \& Purani, K. (2012). Comparing the importance of luxury value perceptions in cross-national contexts. Journal of Business Research, 65 (10), 1417-1424. https://doi.org/10.1016/j.jbusres.2011.10.007

Shunmugam (2015). Consumer intentions of purchasing authentic luxury brands versus counterfeits in South Africa. Gordon Institute of Business Science, University of Pretoria

Smith, R. \& Deppa, B. (2009). Two dimensions of attribute importance. Journal of Consumer Marketing, 26(1), 28-38. https://doi.org/10.1108/07363760910927028

Solomon, M. (2013). Consumer Behavior: Buying, Having and Being. global edn, 10th edn, Pearson

Solomon, M., Bamossy, G., Askegaard, S. \& Hogg, M. (2016). Consumer Behaviour: A European Perspective. 6th edn, Pearson

Tom, G., Barnett, T., Lew, W. \& Selmants, J. (1987). Cueing The Consumer: The Role of Salient Cues in Consumer Perception. Journal of Consumer Marketing, 4 (2), 23-27. https://doi.org/10.1108/eb008193

Tom, G., Garibaldi, B., Zeng, Y. \& Pilcher, J. (1998). Consumer demand for counterfeit goods. Psychology \& Marketing, 15(5), 405-421. https://doi.org/10.1002/(SICI)1520-6793(199808)15:5\%3C405::AID-MAR1\% 3E3.0.CO;2-B

Tsai, H. \& Huang, H. (2007). Determinants of e-repurchase intentions: An integrative model of quadruple retention drivers. Information \& Management, 44(3), 231-239. https://doi.org/10.1016/j.im.2006.11.006

Tsai, S. (2005). Utility, cultural symbolism and emotion: A comprehensive model of brand purchase value. International Journal of Research in Marketing, 22(3), 277-291. https://doi.org/10.1016/j.ijresmar.2004.11.002

Wee, C., Ta, S. \& Cheok, K. (1995). Non - price determinants of intention to purchase counterfeit goods: an exploratory study. International Marketing Review, 12(6), 19-46. https://doi.org/10.1108/02651339510102949

White, L. \& Yanamandram, V. (2004). Why customers stay: reasons and consequences of inertia in financial services. Managing Service Quality, 14 (2/3), 183-194. https://doi.org/10.1108/09604520410528608

White, L. \& Yanamandram, V. (2007). A model of customer retention of dissatisfied business services customers. Managing Service Quality: An International Journal, 17(3), 298-316. https://doi.org/10.1108/09604520710744317

Zeithaml, V., Berry, L. \& Parasuraman, A. (1996). The Behavioral Consequences of Service Quality. Journal of Marketing, 60 (2), 31-46. https://doi.org/10.2307/1251929

Zhang, Z., Li, Y., Gong, C. \& Wu, H. (2002). Casual wear product attributes: A Chinese consumers perspective. Journal of Fashion Marketing and Management: An International Journal, 6(1), 53-62. https://doi.org/10.1108/13612020210422464

Zikmund, W., Babin, B., Carr, J. \& Griffin, M. (2009). Business Research Methods (8th ed.). Cengage Learning

Zineldin, M. (2000). Total relationship management (TRM) and total quality management (TQM). Managerial Auditing Journal, 15(1/2), 20-28. https://doi.org/10.1108/02686900010304399

\section{Copyrights}

Copyright for this article is retained by the author(s), with first publication rights granted to the journal.

This is an open-access article distributed under the terms and conditions of the Creative Commons Attribution license (http://creativecommons.org/licenses/by/4.0/). 